\title{
Balance, falls, and bone health: Role of exercise in reducing fracture risk after stroke
}

\author{
Janice J. Eng, PhD, PT/OT; ${ }^{1-2 *}$ Marco Y. C. Pang, PhD, PT; ${ }^{3}$ Maureen C. Ashe, PhD, PT ${ }^{\mathbf{1}}$ \\ ${ }^{1}$ Department of Physical Therapy and Graduate Program in Rehabilitation Sciences, University of British Columbia, \\ Vancouver, Canada; ${ }^{2}$ GF Strong Rehabilitation Centre, Vancouver, Canada; ${ }^{3}$ Department of Rehabilitation Sciences, \\ Hong Kong Polytechnic University, Hong Kong, China
}

\begin{abstract}
Fractures occur frequently in people living with stroke and have high personal, social, and economic costs for these individuals, their families, and the community. Exercise to reduce the risk of fragility fractures is a relatively new application in stroke rehabilitation but is a promising treatment with the potential to reduce the incidence of falls as well as maintain or improve bone health. In this article, we outline fracture risk factors and provide an overview of exercise interventions aimed at reducing fracture risk poststroke. Although randomized controlled trials support the use of exercise to reduce fracture risk factors poststroke, the body of literature is small and further studies are required. Further, the optimal dose of exercise and the additive effects of pharmacology on fracture risk need to be determined. Given the many health benefits associated with exercise, it should be considered an important modality for the management of falls and maintenance of bone health following stroke.
\end{abstract}

Key words: balance, bone, bone density, CVA, exercise, falls, fracture, osteoporosis, rehabilitation, stroke.

\section{INTRODUCTION}

Stroke is a leading cause of long-term disability, and 90 percent of people living with stroke have some functional limitations [1], including muscle weakness, pain, spasticity, cognitive dysfunction, poor balance, and frequent falls [2]. These impairments can lead to reduced activity and sedentary lifestyles, with further declines in function and disability status. Exercise is a treatment modality that has been typically used during stroke recovery to improve motor function. More recently, exercise has been used to improve cardiovascular health in the attempt to reduce secondary complications such as recurrent stroke and heart disease [3]. Exercise to reduce the risk of fragility fractures is a relatively new application in stroke rehabilitation [4] but is a promising treatment with the potential to reduce the incidence of falls and maintain or improve bone health. Only one intervention has been reported that has specifically tested the effect of exercise on bone health outcomes poststroke, and that trial highlights the feasibility and efficacy of an exercise intervention for reducing fracture risk in people living with stroke [4].

Fragility fractures (i.e., fractures that occur as a result of a fall from standing height or less) are serious medical

Abbreviations: $\mathrm{BBS}=$ Berg Balance Scale, $\mathrm{BMD}=$ bone mineral density, DXA = dual-energy X-ray absorptiometry, FAME = Fitness and Mobility Exercise (Program), ICTP = carboxy-terminal telopeptide of type I collagen, $\mathrm{pQCT}=$ peripheral quantitative computed tomography, $\mathrm{PTH}=$ parathyroid hormone, $\mathrm{SD}=$ standard deviation.

* Address all correspondence to Janice J. Eng, PhD, PT/OT; T325-2211 Wesbrook Mall, Vancouver, BC, V6T 2B5, Canada; 604-714-4105; fax: 604-714-4168.

Email: Janice.Eng@vch.ca

DOI: 10.1682/JRRD.2007.01.0014 
events that have high personal, social, and economic costs for patients, their families, and the wider community [5]. Importantly, the risk of death for patients who have a hip fracture is substantially increased in the first 6 months postfracture and persists for the following 6 years independent of other comorbidities [6]. In the general population, the lifetime cost of hip fractures has been estimated as $\$ 81,300$ U.S. dollars per person [7]. Di Monaco et al. found that people admitted for hip fracture who also had a neurological condition (such as stroke or Parkinson disease) experienced a longer rehabilitation hospital stay compared with people without any accompanying neurological condition [8].

Falls and fractures can also lead to a loss in balance confidence, and people with stroke who have fallen previously have more fear of falling [9]. This reduced confidence in one's abilities contributes to the cycle of sedentary lifestyle and disability. In fact, fear of falling was found to be more important than pain and depression when predicting functional recovery after hip fracture surgery in older adults [10]. Improving balance function has long been a major focus of stroke rehabilitation; however, the role that exercise may play in reducing falls and improving bone health in people with stroke is largely unknown. This review will discuss the role of exercise in reducing fracture risk and fractures following a stroke.

\section{ELEVATED FRACTURE RISK IN PEOPLE LIVING WITH STROKE}

In the first 6 months following a stroke, up to 73 percent of individuals will sustain a fall [11], and within the first year, the risk for a fragility fracture is 4 percent and increases to 15 percent at 5 years poststroke [12]. Fractures of the paretic side are most common with hip fractures occurring most frequently (30\%- $45 \%$ of fractures) followed by wrist fractures (14\%-24\% of fractures) [12$13]$. Kanis et al. analyzed $\sim 273,000$ stroke admissions and reported a sevenfold increase in fracture risk for individuals with stroke within the first year compared with people without stroke [14]. For every 2 standard deviation (SD) decrease in femoral neck bone mineral density (BMD), a sevenfold increase in the risk of a hip fracture was present in people who had previously sustained a stroke [15].

Low-trauma fractures have a number of known risk factors in older adults. Low bone mass [16-17] and fre- quent falls [18-19] are two independent risk factors of fragility fractures that are often observed together. As the majority of people living with a stroke are ambulatory [20], have poor balance, and have lower bone mass in the affected arm or leg, the occurrence of fragility fractures is not surprising. In addition to increased falls and diminished bone mass, several other key determinants of fragility fractures after a stroke exist and are highlighted in the Table. The most notable and consistent risk factor is being a woman [13-14,21]; this may be because women are already at greater risk for fragility fractures due to postmenopausal bone loss. The risk of fracture becomes accentuated when combined with impaired mobility and poor balance. Another key determinant of fragility fractures is the length of hospitalization time from the initial stroke. The effect is dependent on sex, although the reason behind this influence is unknown. For men who sustained a stroke, the risk of a fragility fracture following a stroke increased by 2.3 percent for each 10 additional days in the hospital [14]. Conversely, for women, the risk for fragility fracture decreased with duration of hospital stay following a stroke [14]. Age is an important determinant, with older adults having a higher rate of fragility fractures poststroke [13] and those over 80 years particularly at risk [14]. Other notable factors include a greater severity of hemiparesis [14] and lower cognition [13,21]. Fracture risk is greatest in the first year [14] or two [12] following stroke.

\section{FALL RISK IN PEOPLE LIVING WITH STROKE}

Although frequent falls and low bone mass are both important determinants of fragility fractures, the risk of falling is thought to be the more important factor in older adults [22]. As many as 73 percent of individuals with stroke fall within 6 months of hospital discharge, with an average of 3.4 falls per person during this 6-month time period [11]. Once home, individuals with stroke continue to fall frequently [2,23-24].

Tasks that are associated with falling for people with stroke include walking, turning, transferring, and rising from a chair [23,25-26]. Most falls occur in the home $[11,23,25]$, and the majority of individuals land sideways on their paretic side or on their hands and knees [23]. Factors associated with an increased risk of falls in people with stroke include depression [24,27], cognition [28], increasing age [27], functional disability [27], medications [29], 
Table.

Summary of studies highlighting fracture risk poststroke.

\begin{tabular}{|c|c|c|c|c|}
\hline Study & Participants & Fractures & Risk & Risk Factors \\
\hline $\begin{array}{l}\text { Kanis et al., } 2001 \\
\text { Swedish Hospital } \\
\text { Registry [1] }\end{array}$ & $\begin{array}{l}\text { Records of hospital } \\
\text { admissions for stroke } \\
\text { (1987-1996). Identified } \\
\text { 273,288 persons with } \\
\text { stroke. }\end{array}$ & $\begin{array}{l}8,875 \text { men }(6.5 \%) \& \\
15,791 \text { women }(11.6 \%) \\
\text { had subsequent fracture. } \\
\text { 4,988 men }(3.6 \%) \& \\
9,275 \text { women }(6.8 \%) \\
\text { had hip fracture. }\end{array}$ & $\begin{array}{l}\text { Relative risk for women } \\
\text { aged } 50-54 \text { yr to sustain } \\
\text { hip fracture }=11.75 \text {. }\end{array}$ & $\begin{array}{l}\text { Female sex \& earlier time since } \\
\text { stroke (first yr after stroke has } \\
\text { marked increase in fractures). } \\
\text { Length of hospital stay: longer } \\
\text { admission increased risk for men } \\
\text { but decreased risk for women. }\end{array}$ \\
\hline $\begin{array}{l}\text { Dennis et al., } 2002 \\
\text { Scottish Hospital- } \\
\text { Based Cohort } \\
\text { Study [3] }\end{array}$ & $\begin{array}{l}\text { Follow-up on patients } \\
\text { admitted to hospital } \\
(N=2,696) . \text { Mean age }= \\
68 \pm 14 \text { yr, } 47 \% \text { women. }\end{array}$ & 88 fractures (30\% at hip). & $\begin{array}{l}4 \% \text { sustained any fracture } \\
\text { within } 2 \text { yr \& } 1.1 \% \text { had hip } \\
\text { fracture. } 1.4 \text { times rate of } \\
\text { general population. }\end{array}$ & $\begin{array}{l}\text { Female sex, older age, lower } \\
\text { cognition, \& level of depen- } \\
\text { dence prior to stroke. }\end{array}$ \\
\hline $\begin{array}{l}\text { Whitson et al., } 2006 \\
\text { U.S. Veterans Hospital } \\
\text { Database [4] }\end{array}$ & $\begin{array}{l}\text { Identified } 1,073 \text { veterans } \\
\text { admitted to } 9 \text { hospitals } \\
\text { for stroke. Mean age = } \\
68 \pm 10 \mathrm{yr}, 98 \% \text { men. }\end{array}$ & $\begin{array}{l}51 \text { people sustained } \\
\text { fracture within } 2 \mathrm{yr} \\
\text { of stroke. }\end{array}$ & $\begin{array}{l}\text { Estimated fracture risk } \\
2 \mathrm{yr} \text { poststroke }=6.1 \% \text {. }\end{array}$ & $\begin{array}{l}\text { No significant risk factors but } \\
\text { longer hospitalization \& new } \\
\text { motor or sensory impairment } \\
\text { showed trends toward risk. }\end{array}$ \\
\hline $\begin{array}{l}\text { U.S. Veterans } \\
\text { Integrated Stroke } \\
\text { Outcomes Database }\end{array}$ & $\begin{array}{l}\text { Identified 6,578 veterans } \\
\text { admitted for inpatient } \\
\text { stroke rehabilitation at } \\
121 \text { hospitals during } \\
2001-2002 . \text { Mean age = } \\
68 \pm 11 \text { yr, } 98 \% \text { men. }\end{array}$ & $\begin{array}{l}244 \text { people sustained } \\
\text { fracture within } 2 \mathrm{yr} \\
\text { of stroke. }\end{array}$ & $\begin{array}{l}\text { Estimated fracture risk } \\
2 \text { yr poststroke }=4.7 \% \text {. }\end{array}$ & $\begin{array}{l}\text { Female sex, nonblack race, } \\
\text { \& low cognitive Functional } \\
\text { Independence Measure scores. }\end{array}$ \\
\hline
\end{tabular}

1. Kanis J, Oden A, Johnell O. Acute and long-term increase in fracture risk after hospitalization for stroke. Stroke. 2001;32(3):702-6. [PMID: 11239190]

2. Ramnemark A, Nilsson M, Borssén B, Gustafson Y. Stroke, a major and increasing risk factor for femoral neck fracture. Stroke. 2000;31(7):1572-77. [PMID: 10884456]

3. Dennis MS, Lo KM, McDowall M, West T. Fractures after stroke: Frequency, types, and associations. Stroke. 2002;33(3):728-34. [PMID: 11872896]

4. Whitson HE, Pieper CF, Sanders L, Horner RD, Duncan PW, Lyles KW. Adding injury to insult: Fracture risk after stroke in veterans. J Am Geriatr Soc. 2006;54(7):1082-88. [PMID: 16866679]

urinary incontinence [28], and poor balance [29]. These risk factors have also been reported in the older adult population; however, depression is noteworthy because it occurs so frequently in people living with stroke. As many as 52 percent of people who have had a stroke live with depression [30]. The effects of depression are complex; depressive symptoms can cause a decrease in cognitive function with associated poor judgment that may contribute to falls. Consequently, falls, fear of falling, and the resultant social isolation could also contribute to depression. Furthermore, the use of antidepressant medications has been consistently associated with falls [31].
Stroke-specific impairments such as hemineglect [29] and attention deficits [32] have been also identified as risk factors for falls. Those with right cerebral infarcts are twice as likely to fall as those with left cerebral infarcts, probably because of the visuospatial neglect, proprioceptive impairments, and attention deficits associated with right cerebral infarcts [27]. A stroke can result in a number of visual problems, including visual neglect, decreased visual acuity, diplopia (double-vision), squint, and homonymous hemianopsia (visual field defects). However, studies have not found visual impairments to be important predictors of falls poststroke $[2,24,28]$. In fact, Yates et al. found that the 
addition of visual impairments to motor and sensory impairments reduced the risk of falls and attributed these findings to less mobility and less exposure to fall risk [33].

Given the specific impairments of stroke, traditional fall risk assessments for older adults may not be suitable for people with stroke. For example, "STRATIFY," a fall risk assessment developed for older adults, is based on previous falls, agitation, visual impairment, frequent toileting, and a mobility score and has been validated in older adults but was a poor predictor of falls poststroke [34]. Lamb et al. found that typical fall risk factors identified in older adults such as knee extensor strength, tandem standing balance, gait speed, incontinence, previous falls, and sedative/hypnotic medications did not predict falls in older women with stroke [2]. However, they found a number of self-report measures, such as selfreported balance problems while dressing and spinning stroke symptoms (e.g., vertigo, dizziness), to be predictors. Further, Harris et al. found that neither balance (Berg Balance Scale [BBS] score) nor mobility (gait speed) could explain falls in people with chronic stroke [25]. They suggested that focusing on dynamic activities such as reactive balance and environmental interactions (e.g., stepping over an obstacle) may be necessary when assessing individuals with stroke for risk of falls. Slow postural muscle reflexes may also contribute to falling. Marigold and Eng induced falls in persons with stroke while they were standing on a platform that translated unexpectedly (participants were attached to an overhead harness) [35]. They found that postural leg muscle reflexes in response to the perturbation took longer in those who fell versus those who did not fall. Postural sway when standing [36] and when rising from and sitting down on a chair [37] has also been found to be a risk factor for falls poststroke.

The relationship between fall risk determinants and falling is not always linear. In general, those with greater disability from stroke have been found to have greater fall risk [23]. Harris et al. found that ambulatory individuals with stroke who used a wheelchair or walker for longer distances had poor balance scores (measured by the BBS) and slow gait speed [25]. However, these individuals had a low risk for falls compared with those who used a cane who had better balance scores and faster gait speeds. Thus, the type of assistive device, in addition to exposure to potentially risky situations, may have an effect on falling.

\section{STROKE: A MODEL OF DISUSE OSTEOPOROSIS}

Spaceflight or immobilization cause similar responses in bone and serve as models of disuse osteoporosis. Following a stroke, individuals can have a multitude of impairments that result in compromised functional status, low physical activity, reduced use of the paretic arm and leg, and consequently bone loss overall that is greater on the paretic side. In persons with stroke, BMD on the paretic side has been correlated with muscle strength [38$39]$, muscle atrophy $[38,40]$, degree of motor recovery [41-44], cardiovascular fitness [40], ability to perform functional activities [42,44-45], walking ability [46], weight-bearing ability [47], and amount of skeletal loading [48]. The nonparetic side may also sustain a certain degree of bone loss that is less pronounced when compared with the paretic side [46-47,49]. Such bone changes on the nonparetic side may be due to changes in patterns of habitual use $[48,50]$. The clinical implication is that one may be able to enhance bone health by changing these associated factors, which primarily involve activity and limb use.

Studies on bone health in patients with stroke have revealed three important phenomena related to changes associated with neurological impairments and functional limitations. First, BMD in the paretic limbs is consistently lower than in the nonparetic limbs (by $\leq 20 \%$ ) $[38,40,50$ 54]. The magnitude of the side-to-side difference found in individuals with stroke is much higher than that found between the dominant and nondominant sides in nondisabled older individuals $(<1.5 \%)$ [55], which suggests a pronounced effect of hemiparesis on bone loss.

Second, bone loss is more severe in the paretic upper limb than the paretic lower limb. In a sample of individuals with chronic stroke, Hamdy et al. reported a significant 12.4 percent side-to-side difference in total arm BMD but only a 4.3 percent side-to-side difference in total leg BMD [51]. This discrepancy may be attributable to the greater amount of skeletal loading applied to the legs versus the arms. A large proportion of people living with stroke ( $>60 \%)$ are able to regain standing and some walking function [20]. The ground reaction force produced during walking and transfers thus provides a source of mechanical loading to the paretic leg [48]. In contrast, patients with stroke often use their nonparetic arm to compensate and develop "learned non-use" of the paretic upper limb despite recovery of motor ability [56-57].

Third, the most rapid bone loss occurs in the acute and subacute phase of stroke recovery ( $<6$ months) followed 
by a slower progressive bone loss in the chronic stage $[39,43,46-47,54,58]$. In a 1-year prospective study, those who had severe paresis in the upper limb sustained a 23 percent loss in BMD in the proximal humerus within the first 7 months poststroke and an additional 4 percent loss at 1 year [43]. In contrast, those with mild paresis only sustained a 1 and 4 percent reduction in BMD in the proximal humerus at 7 months and 1 year poststroke, respectively [43]. Similar findings have also been reported in the lower limb [49], although the magnitude of loss is less.

The majority of studies have used dual-energy X-ray absorptiometry (DXA), which is a bone imaging technique that provides a two-dimensional view of bone. On the other hand, pQCT is a bone imaging technique that measures volumetric BMD, evaluates bone geometry, and separates cortical and trabecular bone properties. Cortical bone is found primarily in the shaft of long bones and forms the outer shell around trabecular bone at the end of joints, while trabecular bone is found in the vertebral bodies and fills the ends of long bones.

Two recent studies used peripheral quantitative computed tomography (pQCT) to assess the effect of stroke on bone loss in individuals with chronic stroke (onset $>1$ year) [59-60]. At the distal 4 percent of the radius (primarily trabecular bone and a common site of wrist fractures), 15 percent less total density and 11 percent less total mineral content were found on the paretic side compared with the nonparetic side (Figure 1) [59]. At the distal 30 percent of the radius (primarily cortical bone), significantly lower values of cortical bone mineral content, cortical BMD, and cortical thickness were reported on the paretic side compared with the nonparetic side. Furthermore, bone loss combined with altered geometry resulted in a significantly lower bone strength index on the paretic side [59-60].

Using the nonparetic limb as a "control" limb provides a convenient method to test the effects of disuse on bone loss while providing control for different factors (i.e., absolute bone mass, age, sex, environment) [52,61-62]. However, using the nonparetic limb as the control limb has some limitations. For example, a prospective study by Ramnemark et al. found that BMD in the nonparetic upper limb increased by 3.6 percent within the first year poststroke, likely due to compensatory use [54]. Therefore, the side-to-side difference in BMD between the paretic and nonparetic arms may be partly because of the increased BMD on the nonparetic side.
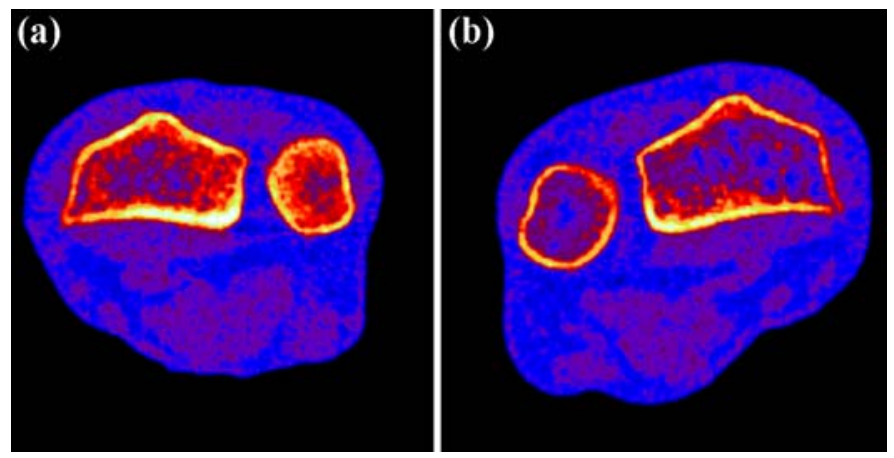

Figure 1.

Peripheral quantitative computed tomography of $4 \%$ site of distal radius of (a) nonparetic and (b) paretic arm of 68-year-old woman who sustained stroke 4 years previously. Note reduction of trabecular bone inside cortical shell of (b) paretic limb. Source: Reprinted by permission from Ashe MC, Fehling P, Eng JJ, Khan KM, McKay HA. Bone geometric response to chronic disuse following stroke: A pQCT study. J Musculoskelet Neuronal Interact. 2006;6(3):226-33.

[PMID: 17142942]

Biochemical analysis, a complementary technique to bone imaging, has shown that individuals with stroke have an elevated serum ionized calcium concentration but a normal level of parathyroid hormone (PTH) $[44,63]$. The results indicate that stroke-induced disuse causes bone loss, leading to increased serum calcium levels, which in turn inhibit PTH secretion and vitamin D production. Studying bone markers also provides a dynamic assessment of bone turnover [44,63-64]. A significant negative correlation was found between the level of NTx (urinary cross-linked N-telopeptides of type I collagen, a bone resorption marker) and degree of motor recovery and walking ability [64]. Other studies have also found that individuals with stroke have lower levels of intact bone Gla protein (gamma-carboxyglutamate, a bone formation marker) $[44,63,65]$ but higher levels of pyridinoline cross-linked carboxy-terminal telopeptide of type I collagen (ICTP, a bone resorption marker) when compared with nondisabled control subjects [63,65]. The level of ICTP tends to be negatively correlated with poststroke duration, which indicates that a high rate of bone resorption may occur during the early stage of stroke [66-67]. This finding is consistent with the imaging studies that show that the rate of bone loss is the most rapid in the early stage of stroke recovery $[43,46-47,54]$. 


\section{ROLE OF EXERCISE IN REDUCING FRACTURE RISK}

Exercise has the potential to improve balance, reduce falls, and improve bone density. Thus, it would be logical that the sum of these effects would result in a reduction in fractures. Randomized prospective trials have shown that exercise can affect surrogate end points for fractures, such as falls and BMD; however, a trial with enough statistical power to show an exercise-associated reduction in fractures in people with stroke or even in the general population has not been conducted. Karlsson emphasized that the null hypothesis "exercise has no effect on fracture rates in older adults" cannot be rejected based on any published, randomized prospective data [68]. Rather, the role of exercise in reducing bone fractures is supported by lower levels of evidence in case control and cohort studies (e.g., those with a history of physical activity have a reduced fracture risk).

Methodological limitations make evaluating the effect of exercise on reducing fractures challenging. Falls resulting in fractures are relatively infrequent in relation to the high number of falls, and consequently, large sample sizes are required to detect the infrequent event of a fracture. For example, in a study assessing oral folate with vitamin B12, Sato et al. estimated that given a 10 percent fracture rate in a sample size of 560 people with stroke, researchers could detect a 64 percent reduction in the risk of hip fractures with a power of 80 percent and a $p$-value of 0.05 [69]. Current literature suggests that pharmacological interventions can reduce the risk of fracture by more than 50 percent in some cases [68]; however, exercise interventions generally have a small effect on outcome measures. Thus, an extremely large study would be required to detect a clinically significant effect on fracture risk. It has been estimated that using fracture as the clinical end point for an exercise intervention would require 7,000 participants at a minimum and extend for at least 5 years [70].

\section{Exercise to Reduce Falls Poststroke}

A number of randomized controlled exercise interventions in people with stroke have resulted in improvements in fall risk factors demonstrated by outcomes such as balance, weight-bearing ability, gait, and mobility [4,71-73] but only a handful have specifically addressed the outcome of falls.

Cheng et al. used a biofeedback system to reduce the frequent falls that occur early after a stroke [74]. They assessed 54 patients undergoing stroke rehabilitation who were between 2 and 4 months postinjury. Participants in the experimental group received biofeedback during 30 minutes of symmetrical standing and 20 minutes of repetitive sit-to-stand training for 5 days a week for 3 weeks in addition to conventional therapy. The control group only received conventional therapy. At the 6-month follow-up, only 16.7 percent of the experimental group had experienced a fall, while 41.7 percent of the control group had fallen. One important consideration is that although some of the conventional therapy time of the experimental group was reduced to accommodate the biofeedback training, the experimental group appears to have received more hours of therapy than the control group; the fact that additional hours of inpatient stroke rehabilitation therapy do result in beneficial outcomes is well established [75].

Marigold et al. used a 10-week (1 hour, 3 times a week) group exercise intervention to reduce falls in communitydwelling individuals with stroke [76]. The experimental group (Agility, $n=30$ ) and the control group (WeightShifting and Stretching, $n=31$ ) both improved functional balance (BBS score) and mobility (Timed Up and Go Test). The Agility intervention focused on functional strengthening (e.g., repetitive sit-to-stand, stepping up on a stepper while holding a support), variation in movement speed between slow and fast, balance in various postures (e.g., tandem, weight-shifting), and walking with various challenges (e.g., different step lengths and speeds, tandem walking, figure eight walking, stepping up and over low risers); additional exercises included standing perturbations (i.e., instructor pushing participant in a controlled manner or participant pushing instructor to destabilize balance and elicit postural reflexes). For individuals who had a prior history of falls, those in the Agility group experienced significantly fewer falls (8/15) in the community compared with the Weight-Shifting and Stretching group (13/15) in the 12 months following the intervention. Fall data were collected prospectively by monthly fall diaries.

One small study $(n=10)$ with encouraging results was an intensive massed practice program (6 hours a day, 5 days a week of one-on-one training for 10 weeks) for patients with chronic stroke that focused on strengthening, range of motion, aerobic conditioning, balance activities, functional training, and education [77]. A reduced number of falls in the year following the intervention was documented [77]; however, caution should be used when interpreting these fall results since the study was not a controlled trial and the number of falls in the year prior to the intervention were collected by recall. Fall history 
recall can be prone to underreporting, especially when collected over a long period rather than at shorter intervals (e.g., monthly) [78]. However, the intervention is innovative with promising results and in part emulates the successful constraint-induced therapy approach used with the upper limb poststroke. [79]

In contrast to the previous studies, Green et al. found small transitory mobility improvements in people with chronic stroke (85 controls, 85 treatment) but no overall effect on reported falls using an individualized physiotherapy program (home or outpatient rehabilitation center) [80]. However, the lack of effect could be attributed to the low amount of treatment because the median number of treatments per patient was only three with a mean duration of 44 minutes.

What are the key mechanisms that resulted in fall reduction in these studies involving people with stroke? The three studies that reduced falls used repetitive functional tasks that most likely increased motor coordination, improved movement speed, and challenged muscle strength [74,76-77]. Task-specific interventions may be particularly important in stroke where altered motor coordination is present. In addition, symmetrical weightbearing through the paretic limb was emphasized through the tasks. Postural control, weight-bearing symmetry, and movement speed can be improved with exercise poststroke and may contribute to a reduction of falls. Cheng et al. reported that their biofeedback group demonstrated reduced postural sway, a greater rate of rise in force, and more weight-bearing symmetry during their sit-to-stand task [74]. The agility training in the Marigold et al. study resulted in faster reflexes to standing postural perturbations compared with the Weight-Shifting and Stretching group (Figure 2) [76]. Such observations suggest that appropriately timed postural reflexes in response to a destabilizing event may prevent a fall. In addition, Marigold et al. found that step reaction time (time to complete a voluntary step forward when cued) was also reduced in the Agility group [76]. Similarly, Vearrier et al. found that the time to stabilize standing posture following a translating platform perturbation, in addition to weightbearing symmetry, was improved following their practice program [77].

The attention from the therapist or the social support of the group intervention may have improved factors such as depression or cognitive function that have been linked to falls. In addition, improvements in functional ability may have increased participation in regular physical activity or exercise, particularly once the intervention ended. (a)

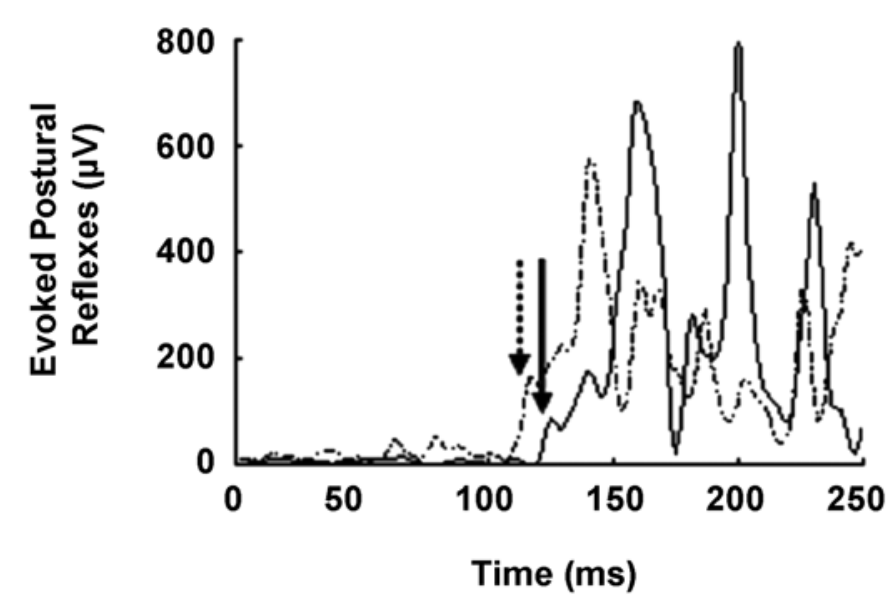

(b)

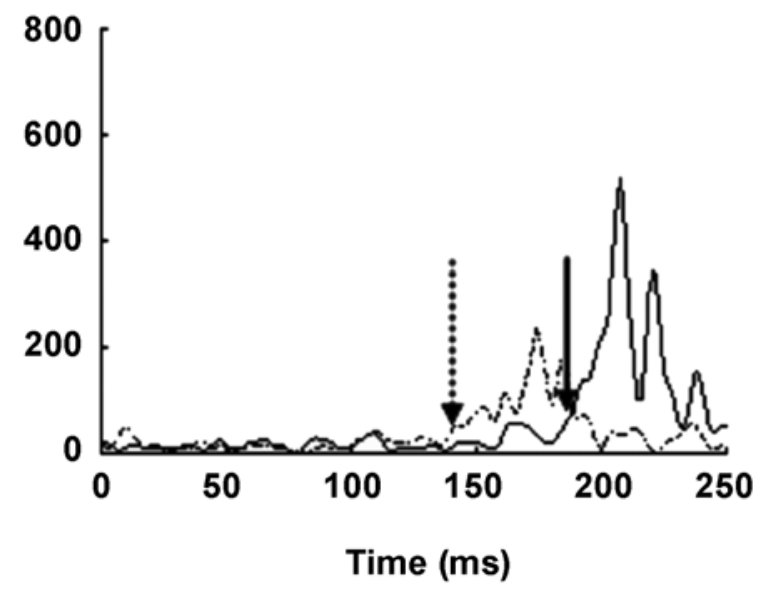

Figure 2.

Typical paretic postural reflexes evoked in response to forward platform translation while standing in individual with stroke for (a) tibialis anterior and (b) rectus femoris. Solid line: Baseline assessment prior to 10-week Agility intervention. Dashed line: Assessment after 10-week Agility intervention. Platform translations triggered at time zero. Arrows (solid for baseline assessment and dashed for postintervention assessment) indicate reflex activation. Note earlier reflex following intervention. Source: Reprinted by permission from Marigold DS, Eng JJ, Dawson AS, Inglis JT, Harris JE, Gylfadóttir S. Exercise leads to faster postural reflexes, improved balance and mobility, and fewer falls in older persons with chronic stroke. J Am Geriatr Soc. 2005;53(3):416-23. [PMID: 15743283] 
A missing element in most exercise interventions is the optimum dose of exercise required to reduce falls and improve other outcomes. A once-weekly training compared favorably with both twice-weekly and thrice-weekly training among 65-to-75-year-old adults on muscle and balance outcomes [81]. However, the work of Vearrier et al. suggests that high volumes of exercise (6 hours daily) may be necessary to produce positive falls outcomes in people with stroke [77]. The optimum dose of exercise is an important area that has not been adequately addressed in the literature, yet is essential for guiding appropriate exercise prescription.

\section{Exercise to Improve and Maintain Bone Health Poststroke}

Physical inactivity has long been identified as a risk factor for osteoporosis [82-84]. Increasing physical activity through specific exercise training may therefore be an effective strategy for enhancing bone health. The combination of muscle loading and ground reaction forces produced during exercise may provide the mechanical strain necessary for enhancing bone mass [85]. Generally speaking, the magnitude of gain in BMD (as measured by DXA) at various skeletal sites varies from 1 to 7 percent following exercise training for 6 months to 1 year in older adults [64,86-91], with the majority of these studies reporting a gain in BMD between 0 and 3 percent [86,88-92].

Exercise also has effects on volumetric bone density and bone geometry in older adults [93-94]; pQCT has shown increases in cortical bone density in the long bones (e.g., tibia, radius). Adami et al. also reported an increase in total cross-sectional area (2.6\%) in the ultradistal radius following exercise training in postmenopausal women, which indicates periosteal apposition (adding bone to the periosteal surface) [93]. Such phenomena enhance bone strength by increasing the crosssectional moment of inertia [95].

Only one randomized controlled trial has examined the effects of exercise on bone health in people with stroke $[4,96]$. The exercise program was the 19-week communitybased Fitness and Mobility Exercise (FAME) Program (http://www.icord.org/fame.html) for ambulatory individuals with chronic stroke. The exercises were designed to address multiple physical impairments such as muscle weakness, balance deficits, and poor aerobic fitness. One of the important features of this program was that it provided a variety of weight-bearing activities (e.g., sit-to-stand, stepping onto risers, brisk walking) to load the lower limbs in addition to a significant cardiovascular training component. Following the 19-week exercise program, the FAME group $(n=32)$ had a significantly greater improvement in walking endurance, paretic leg muscle strength, and aerobic capacity when compared with the control group $(n=31)$ (seated arm exercise program) (Figure 3). In addition, femoral neck BMD on the paretic side (measured by DXA) was not significantly changed in the FAME group ( $0.7 \%$ decline), whereas the control group had a significant 2.5 percent decline [4]. The loss of BMD in the control group was clinically significant since the rate of decline in femoral neck BMD among older men and women (60-69 years) is only 0.5 and 0.9 percent per year, respectively. Such an exaggerated rate of bone loss in individuals with stroke is alarming given that the osteoporotic fracture risk would be increased by 1.10 and 2.43 in men and women, respectively, for every 1 SD decline in femoral neck BMD [97]. In addition, individuals with stroke have a much higher incidence of falls than the reference population [2], thus any deviation from healthy BMD values would further increase the risk of bone fractures.

In addition, the effects of the FAME Program on bone geometry have been evaluated with pQCT [96]. Following the 19-week exercise program, the intervention group had a significant 5.6 percent increase in trabecular bone mineral content at the distal 4 percent tibial site (primarily trabecular bone) on the paretic side compared with a 0.5 percent decrease in the control group. At the 50 percent tibial site (primarily cortical bone) on the paretic side, the intervention group had a small increase in cortical thickness $(0.4 \%)$, whereas the control group sustained a significant 0.9 percent decrease. The clinical importance of these geometric alterations is uncertain. For example, we do not know whether the reported increase in trabecular bone mineral content and cortical thickness would translate into a reduction in fracture risk.

Although no actual increase in femoral neck BMD was found in the FAME group, the results nevertheless show that exercise can effectively maintain BMD and alter bone geometry in patients with stroke. The protective effect of exercise on bone is also comparable to that obtained by treatment with pharmacological agents or mineral-vitamin supplements in those with stroke $[65,67,98]$. The majority of these studies show that while pharmacological treatment attenuates the reduction of BMD on the paretic side in patients with stroke, it does not produce a significant gain in BMD [65,98-99]. For example, in a study examining the effects of ipriflavone and vitamin D3 on BMD of the 


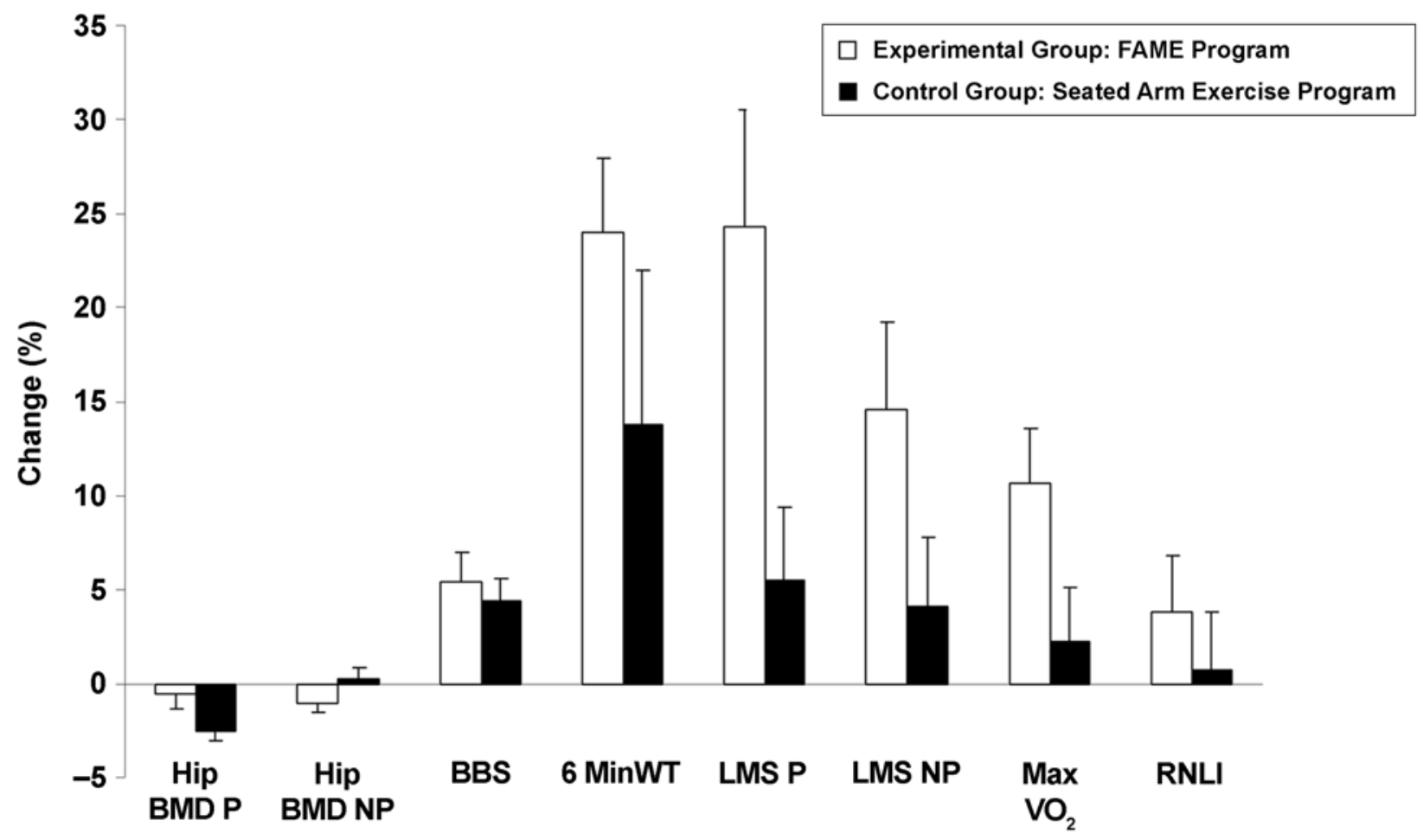

Figure 3.

Percent changes for experimental group (Fitness and Mobility Exercise [FAME] Program) $(n=32)$ (white) and control group (seated arm exercise group) ( $n=31$ ) (black). Significant group differences found for paretic (P) hip bone mineral density (BMD), 6-minute walk test (6 MinWT), leg muscle strength (LMS), and maximal oxygen consumption $\left(\mathrm{Max} \mathrm{VO}_{2}\right)$. BBS = Berg Balance Scale, $\mathrm{NP}=$ nonparetic, $\mathrm{RNLI}=\mathrm{Reintegration}$ to Normal Living Index.

second metacarpal in a sample of chronic stroke patients (onset $>1$ year), the BMD on the paretic side decreased by 1.4 percent in the treatment group and 5.4 percent in the control group within a 1-year period [99].

What are the possible mechanisms of the observed improvements in bone health induced by exercise in the patients with stroke? First, muscle weakness and atrophy on the paretic side are common [38,40,100]. Muscle weakness and lean mass have a strong relationship with BMD in this group [38-40], just as in other populations [101-102]. A muscle-bone relationship is not surprising, given that muscle forces provide mechanical strain essential for bone formation [103]. Bone health may be enhanced through improvement of muscle strength and preservation of muscle mass.

Second, the ground reaction force produced during the weight-bearing exercises may provide novel mechanical stress to the skeleton, beyond that experienced in daily activities. The provision of a different strain environment is believed to be essential to inducing bone formation
[85]. It would be important in future studies to measure ground reaction force during different activities so that the amount of loading applied in a given exercise session could be quantified and compared with any bone changes.

Third, the individuals in the training group reported more gain in ambulatory capacity [4], which may have improved their physical activity level and in turn produced positive effects on bone health. This is consistent with the findings by Worthen et al., who developed the Bone Density Index to quantify gait-related skeletal loading [48]. The computation of the Bone Density Index incorporates ground reaction force magnitude as well as the number of loading cycles per day. They found that proximal femoral BMD is significantly correlated with the Bone Density Index among individuals with chronic stroke, which indicates the important influence of the amount of ambulatory activity on bone health.

Finally, the participants improved in cardiovascular fitness, as measured by maximal oxygen consumption [4]. The positive effects of exercise on bone may be mediated 
by cardiovascular mechanisms. Increasing evidence suggests a link between osteoporosis and cardiovascular diseases [104]. As bone is highly vascular and is in close contact with the endothelium, vascular health may well be a significant factor in influencing bone health [104]. Indeed, myocardial infarction has been associated with low BMD [105]. An increased risk of cardiovascular death for each 1 SD decrease in bone mass has been demonstrated [106], and vascular calcification is associated with a higher relative risk of vertebral fractures [107]. It is also noteworthy that a class of cholesterol-lowering drugs known as statins has been shown to induce bone formation in cell cultures and rodents [108-110], although the findings in humans are inconclusive [111-112]. Aerobic exercise has favorable effects on lipid profiles [113-115] and endothelial function [116-118]. Therefore, the gain in bone health could be partly attributable to improvement in cardiovascular function. This finding is particularly relevant since up to 75 percent of individuals with stroke have some form of cardiovascular disease [119].

The ideal exercise protocol to enhance bone health in patients with stroke is unknown. Animal studies have provided some insight into the effects of different loading protocols on bone formation. Dynamic loading, rather than static loading, is more effective in initiating bone formation [103], and the rate of bone formation is positively related to the loading frequency [120]. In addition, bone tissue becomes desensitized to prolonged exercise very rapidly [121-122]. For example, rats trained to jump 100 times a day did not improve their bone mass significantly beyond those trained to jump only 40 times a day. Other experiments also found that bone formation response becomes saturated within 100 loading cycles [123-124]. Finally, the frequency of exercise sessions also seems to have an effect on the rate of bone formation. Inserting rest periods significantly enhances bone formation compared with continuous loading cycles [124]. However, the effects of these different loading protocols in humans have not been studied.

In human studies, we know that high-impact activities (e.g., gymnastics, jumping) produce a much higher gain in BMD [125-132] than lower-impact activities (e.g., swimming, cycling, walking) [133-135]. Weight training with high loads and low repetitions also results in more gain in BMD than training programs with low loads and high repetitions [136]. Although a higher loading magnitude and frequency may produce the best bone health outcome, other important factors to consider in exercise prescription for people with stroke are cardiovascular fitness, balance abil- ity, sensory deficits, and fatigue. The level of loading required to induce osteogenesis may vary for different individuals with different bone status or disability levels and will require further study. Moreover, exercises may need to be introduced more gradually because many individuals with stroke have been living a sedentary lifestyle and are physically unfit [40]. The optimal exercise protocol for enhancing bone health in people with stroke who have different levels of disability awaits further research.

\section{COMBINING EXERCISE WITH OTHER INTERVENTIONS TO REDUCE FRACTURE RISK}

Given that multiple factors underlie fracture risk, combination therapies may be the most effective treatment for preventing fractures. Jensen et al. assessed 9 residential care facilities with a sample of 402 residents ( $1 / 3$ with previous stroke) [137]. They undertook an 11-week multidisciplinary program that included weekly team meetings to discuss fall reports, staff discussions on safe mobility (e.g., level of appropriate supervision, transfer techniques, bed alarms), environmental modifications (e.g., removing hazards, installing grip bars, enhancing lighting), supervised exercise (17\% of participants), supply or repair of mobility-related aids (7\%), change in medications (12\%), and provision of hip protectors (8\%). Compared with the usual care control group, the multidisciplinary approach resulted in fewer residents who fell, fewer falls, and fewer femoral fractures.

Hip protectors consist of a shield or pad placed strategically in the sides of undergarments and are designed to absorb energy in the event of a fall to prevent a fracture. Hip protectors have been shown to halve the risk of hip fractures in an older adult sample, of which 15 to 21 percent had had a previous stroke [138]. In a recent investigation that was aimed at defining who is the best candidate for hip protectors, significant predictor variables included being an older women, living in a nursing home, being dependent for activities of daily living, taking antipsychotic medications, and having a history of stroke or Parkinson disease [139]. Although hip protectors offer some health benefits, significant barriers to wearing them exist such as aesthetics and donning-doffing the garments [140]. Notably, hip protectors are frequently used during exercise programs, particularly those with agility components, as a safety precaution to reduce the risk of a fracture if a fall should occur during a challenging task [96,141]. 
Medications are widely prescribed for preventing and treating low bone mass. A number of different pharmacological options exist for treating osteoporosis, and these are broadly divided into antiresorptives (medications that reduce bone resorption, the process that removes old bone) and anabolics (medications that stimulate cells to add new bone). Antiresorptives include bisphosphonates, estrogen, selective estrogen receptor modulators, and calcitonin. Intermittent teriparatide (PTH) is an anabolic treatment option that is used for women at very high risk of fragility fracture.

The first line of treatment for bone health is bisphosphonates, and their efficacy has been established in older postmenopausal women. In a meta-analysis, etidronate has been shown to reduce vertebral fractures and increase bone density in the lumbar spine and femoral neck [142]. Sato and coworkers have shown the efficacy of risedronate (a bisphosphonate more potent than etidronate) in preventing hip fractures in older men early after a stroke [143]. In the older adult population, several studies have examined the combination of exercise and drug therapy for maintaining optimal bone homeostasis. For example, Uusi-Rasi et al. used a randomized controlled trial to examine the role of exercise and alendronate (bisphosphonate) in postmenopausal women [144]. In this trial, the women taking bisphosphonate increased bone mass of the lumbar spine and femoral neck but no interactive or additive effect of alendronate and exercise on BMD was noted. However, at the distal tibia, alendronate and exercise had a beneficial effect on bone mass, while exercise improved bone geometric properties.

Low-dose vitamin D has been found to reduce hip fractures in women after stroke by increasing the relative number and size of type II muscle fibers, improving muscle strength, and reducing the number of falls [145]. The addition of exercise to vitamin $\mathrm{D}$ therapy may be an ideal combination because improvements in strength from the vitamin D therapy can be transferred to functional tasks through complementary task-specific exercises. Investigating the combination of pharmacological therapy with exercise in patients with stroke is an area that requires further research.

\section{CLINICAL IMPLICATIONS AND FUTURE DIRECTIONS}

To date, although a trial with enough statistical power to show an exercise-associated reduction in frac- tures for any population has not been conducted, evidence exists that highlights the benefits of exercise for improving bone mass, reducing falls, and improving balance following a stroke. Future studies need to explore the more practical issues related to exercise prescription for fall and fracture prevention for those people who sustain a stroke. No studies have tested the optimal exercise prescription (dose) for improving or maintaining bone health either in the general population or for people who have had a stroke specifically. This optimal dose is an important area that has not been adequately addressed in the literature, and future studies are essential in order to define best practices for exercise prescription and better define exercise programs for people at risk for falls and fractures.

Given the multiple fracture risk factors in virtually every person with stroke [146], the prevention of fragility fractures should be a priority in people with stroke. The use of exercise is an important modality that can reduce multiple fracture risk factors and should be considered for the management of falls and maintenance of bone mass following a stroke.

\section{ACKNOWLEDGMENTS}

Dr. Eng is supported by career scientist awards from the Michael Smith Foundation of Health Research and the Canadian Institutes of Health Research. Dr. Ashe is supported by a postdoctoral fellowship from the Michael Smith Foundation of Health Research.

The authors have declared that no competing interests exist.

\section{REFERENCES}

1. Gresham GE, Fitzpatrick TE, Wolf PA, McNamara PM, Kannel WB, Dawber TR. Residual disability in survivors of stroke-The Framingham study. N Engl J Med. 1975; 293(19):954-56. [PMID: 1178004]

2. Lamb SE, Ferrucci L, Volapto S, Fried LP, Guralnik JM; Women's Health and Aging Study. Risk factors for falling in home-dwelling older women with stroke: The Women's Health and Aging Study. Stroke. 2003;34(2):494-501. [PMID: 12574566]

3. Ivey FM, Hafer-Macko CE, Macko RF. Exercise rehabilitation after stroke. NeuroRx. 2006;3(4):439-50.

[PMID: 17012057] 
4. Pang MY, Eng JJ, Dawson AS, McKay HA, Harris JE. A community-based fitness and mobility exercise program for older adults with chronic stroke: A randomized, controlled trial. J Am Geriatr Soc. 2005;53(10):1667-74.

[PMID: 16181164$]$

5. Cooper C. The crippling consequences of fractures and their impact on quality of life. Am J Med. 1997;103(2A): 12S-19S. [PMID: 9302893]

6. Farahmand BY, Michaëlsson K, Ahlbom A, Ljunghall S, Baron JA; Swedish Hip Fracture Study Group. Survival after hip fracture. Osteoporos Int. 2005;16(12):1583-90. [PMID: 16217590]

7. Braithwaite RS, Col NF, Wong JB. Estimating hip fracture morbidity, mortality and costs. J Am Geriatr Soc. 2003;51(3):364-70. [PMID: 12588580]

8. Di Monaco M, Vallero F, Di Monaco R, Mautino F, Cavanna A. Functional recovery and length of stay after hip fracture in patients with neurologic impairment. Am J Phys Med Rehabil. 2003;82(2):143-51,157.

[PMID: 12544761]

9. Belgen B, Beninato M, Sullivan PE, Narielwalla K. The association of balance capacity and falls self-efficacy with history of falling in community-dwelling people with chronic stroke. Arch Phys Med Rehabil. 2006;87(4):554-61. [PMID: 16571397]

10. Oude Voshaar RC, Banerjee S, Horan M, Baldwin R, Pendleton N, Proctor R, Tarrier N, Woodward Y, Burns A. Fear of falling more important than pain and depression for functional recovery after surgery for hip fracture in older people. Psychol Med. 2006;36(11):1635-45. [PMID: 16863598]

11. Forster A, Young J. Incidence and consequences of falls due to stroke: A systematic inquiry. BMJ. 1995;311(6997): 83-86. [PMID: 7613406]

12. Ramnemark A, Nyberg L, Borssén B, Olsson T, Gustafson Y. Fractures after stroke. Osteoporos Int. 1998;8(1):92-95. [PMID: 9692083]

13. Dennis MS, Lo KM, McDowall M, West T. Fractures after stroke: Frequency, types, and associations. Stroke. 2002;33(3):728-34. [PMID: 11872896]

14. Kanis J, Oden A, Johnell O. Acute and long-term increase in fracture risk after hospitalization for stroke. Stroke. 2001;32(3):702-6. [PMID: 11239190]

15. Browner WS, Pressman AR, Nevitt MC, Cauley JA, Cummings SR. Association between low bone density and stroke in elderly women. The study of osteoporotic fractures. Stroke. 1993;24(7):940-46. [PMID: 8322393]

16. Brown JP, Josse RG; Scientific Advisory Council of the Osteoporosis Society of Canada. 2002 clinical practice guidelines for the diagnosis and management of osteoporosis in Canada. CMAJ. 2002;167(10 Suppl):S1-34.

[PMID: 12427685]
17. Marshall D, Johnell O, Wedel H. Meta-analysis of how well measures of bone mineral density predict occurrence of osteoporotic fractures. BMJ. 1996;312(7041):1254-59. [PMID: 8634613]

18. Nguyen ND, Pongchaiyakul C, Center JR, Eisman JA, Nguyen TV. Identification of high-risk individuals for hip fracture: A 14-year prospective study. J Bone Miner Res. 2005;20(11):1921-28. [PMID: 16234964]

19. Dargent-Molina P, Douchin MN, Cormier C, Meunier PJ, Bréart G; EPIDOS Study Group. Use of clinical risk factors in elderly women with low bone mineral density to identify women at higher risk of hip fracture: The EPIDOS prospective study. Osteoporos Int. 2002;13(7):593-99. [PMID: 12111021]

20. Jørgensen HS, Nakayama H, Raaschou HO, Olsen TS. Stroke. Neurologic and functional recovery: The Copenhagen Stroke Study. Phys Med Rehabil Clin N Am. 1999; 10(4):887-906. [PMID: 10573714]

21. Whitson HE, Pieper CF, Sanders L, Horner RD, Duncan PW, Lyles KW. Adding injury to insult: Fracture risk after stroke in veterans. J Am Geriatr Soc. 2006;54(7):1082-88. [PMID: 16866679]

22. Kannus P, Uusi-Rasi K, Palvanen M, Parkkari J. Nonpharmacological means to prevent fractures among older adults. Ann Med. 2005;37(4):303-10. [PMID: 16019730]

23. Hyndman D, Ashburn A, Stack E. Fall events among people with stroke living in the community: Circumstances of falls and characteristics of fallers. Arch Phys Med Rehabil. 2002;83(2):165-70. [PMID: 11833018]

24. Jørgensen L, Engstad T, Jacobsen BK. Higher incidence of falls in long-term stroke survivors than in population controls: Depressive symptoms predict falls after stroke. Stroke. 2002;33(2):542-47. [PMID: 11823667]

25. Harris JE, Eng JJ, Marigold DS, Tokuno CD, Louis CL. Relationship of balance and mobility to fall incidence in people with chronic stroke. Phys Ther. 2005;85(2):150-58. [PMID: 15679466]

26. Mackintosh SF, Goldie P, Hill K. Falls incidence and factors associated with falling in older, community-dwelling, chronic stroke survivors ( $>1$ year after stroke) and matched controls. Aging Clin Exp Res. 2005;17(2):74-81. [PMID: 15977453]

27. Ugur C, Gücüyener D, Uzuner N, Ozkan S, Ozdemir G. Characteristics of falling in patients with stroke. J Neurol Neurosurg Psychiatry. 2000;69(5):649-51. [PMID: 11032620]

28. Tutuarima JA, Van der Meulen JH, De Haan RJ, Van Straten A, Limburg M. Risk factors for falls of hospitalized stroke patients. Stroke. 1997;28(2):297-301. [PMID: 9040678]

29. Mackintosh SF, Hill KD, Dodd KJ, Goldie PA, Culham EG. Balance score and a history of falls in hospital predict 
recurrent falls in the 6 months following stroke rehabilitation. Arch Phys Med Rehabil. 2006;87(12):1583-89.

[PMID: 17141637]

30. Kotila M, Numminen H, Waltimo O, Kaste M. Depression after stroke: Results of the FINNSTROKE Study. Stroke. 1998;29(2):368-72. [PMID: 9472876]

31. Ensrud KE, Blackwell T, Mangione CM, Bowman PJ, Bauer DC, Schwartz A, Hanlon JT, Nevitt MC, Whooley MA; Study of Osteoporotic Fractures Research Group. Central nervous system active medications and risk for fractures in older women. Arch Intern Med. 2003;163(8): 949-57. [PMID: 12719205]

32. Hyndman D, Ashburn A. People with stroke living in the community: Attention deficits, balance, ADL ability and falls. Disabil Rehabil. 2003;25(15):817-22. [PMID: 12851091]

33. Yates JS, Lai SM, Duncan PW, Studenski S. Falls in community-dwelling stroke survivors: An accumulated impairments model. J Rehabil Res Dev. 2002;39(3):385-94. [PMID: 12173758]

34. Smith J, Forster A, Young J. Use of the 'STRATIFY' falls risk assessment in patients recovering from acute stroke. Age Ageing. 2006;35(2):138-43. [PMID: 16368736]

35. Marigold DS, Eng JJ. Altered timing of postural reflexes contributes to falling in persons with chronic stroke. Exp Brain Res. 2006;171(4):459-68. [PMID: 16418855]

36. Sackley CM. Falls, sway, and symmetry of weight-bearing after stroke. Int Disabil Stud. 1991;13(1):1-4. [PMID: 1917796]

37. Cheng PT, Liaw MY, Wong MK, Tang FT, Lee MY, Lin PS. The sit-to-stand movement in stroke patients and its correlation with falling. Arch Phys Med Rehabil. 1998; 79(9):1043-46. [PMID: 9749681]

38. Pang MY, Eng JJ. Muscle strength is a determinant of bone mineral content in the hemiparetic upper extremity: Implications for stroke rehabilitation. Bone. 2005;37(1): 103-11. [PMID: 15869927]

39. Hamdy RC, Moore SW, Cancellaro VA, Harvill LM. Long-term effects of strokes on bone mass. Am J Phys Med Rehabil. 1995;74(5):351-56. [PMID: 7576411]

40. Pang MY, Eng JJ, McKay HA, Dawson AS. Reduced hip bone mineral density is related to physical fitness and leg lean mass in ambulatory individuals with chronic stroke. Osteoporos Int. 2005;16(12):1769-79. [PMID: 15902416]

41. Iwamoto J, Tsukimura T, Takeda T. Bone mineral density of metatarsus in hemiplegic subjects. Am J Phys Med Rehabil. 1999;78(3):202-7. [PMID: 10340415]

42. Yavuzer G, Ataman S, Süldür N, Atay M. Bone mineral density in patients with stroke. Int J Rehabil Res. 2002; 25(3):235-39. [PMID: 12352178]

43. Jørgensen L, Jacobsen BK. Functional status of the paretic arm affects the loss of bone mineral in the proxi- mal humerus after stroke: A 1-year prospective study. Calcif Tissue Int. 2001;68(1):11-15. [PMID: 12037618$]$

44. Sato Y, Kuno H, Asoh T, Honda Y, Oizumi K. Effect of immobilization on vitamin $\mathrm{D}$ status and bone mass in chronically hospitalized disabled stroke patients. Age Ageing. 1999;28(3):265-69. [PMID: 10475862]

45. Liu M, Tsuji T, Higuchi Y, Domen K, Tsujiuchi K, Chino $\mathrm{N}$. Osteoporosis in hemiplegic stroke patients as studied with dual-energy X-ray absorptiometry. Arch Phys Med Rehabil. 1999;80(10):1219-26. [PMID: 10527077]

46. Jørgensen L, Jacobsen BK, Wilsgaard T, Magnus JH. Walking after stroke: Does it matter? Changes in bone mineral density within the first 12 months after stroke. A longitudinal study. Osteoporos Int. 2000;11(5):381-87. [PMID: 10912838]

47. Jørgensen L, Crabtree NJ, Reeve J, Jacobsen BK. Ambulatory level and asymmetrical weight bearing after stroke affects bone loss in the upper and lower part of the femoral neck differently: Bone adaptation after decreased mechanical loading. Bone. 2000;27(5):701-7. [PMID: 11062359]

48. Worthen LC, Kim CM, Kautz SA, Lew HL, Kiratli BJ, Beaupre GS. Key characteristics of walking correlate with bone density in individuals with chronic stroke. J Rehabil Res Dev. 2005;42(6):761-68. [PMID: 16680613]

49. Ramnemark A, Nyberg L, Lorentzon R, Olsson T, Gustafson Y. Hemiosteoporosis after severe stroke, independent of changes in body composition and weight. Stroke. 1999; 30(4):755-60. [PMID: 10187874]

50. Beaupre GS, Lew HL. Bone-density changes after stroke. Am J Phys Med Rehabil. 2006;85(5):464-72.

[PMID: 16628156]

51. Hamdy RC, Krishnaswamy G, Cancellaro V, Whalen K, Harvill L. Changes in bone mineral content and density after stroke. Am J Phys Med Rehabil. 1993;72(4):188-91. [PMID: 8363812]

52. Prince RL, Price RI, Ho S. Forearm bone loss in hemiplegia: A model for the study of immobilization osteoporosis. J Bone Miner Res. 1988;3(3):305-10. [PMID: 3213623]

53. Takamoto S, Masuyama T, Nakajima M, Seikiya K, Kosaka H, Morimoto S, Ogihara T, Onishi T. Alterations of bone mineral density of the femurs in hemiplegia. Calcif Tissue Int. 1995;56(4):259-62. [PMID: 7767834]

54. Ramnemark A, Nyberg L, Lorentzon R, Englund U, Gustafson Y. Progressive hemiosteoporosis on the paretic side and increased bone mineral density in the nonparetic arm the first year after severe stroke. Osteoporos Int. 1999; 9(3):269-75. [PMID: 10450417]

55. Taaffe DR, Lewis B, Marcus R. Quantifying the effect of hand preference on upper limb bone mineral and soft tissue composition in young and elderly women by dual-energy X-ray absorptiometry. Clin Physiol. 1994;14(4):393-404. [PMID: 7955937] 
56. Wolf SL, Lecraw DE, Barton LA, Jann BB. Forced use of hemiplegic upper extremities to reverse the effect of learned nonuse among chronic stroke and head-injured patients. Exp Neurol. 1989;104(2):125-32. [PMID: 2707361]

57. Taub E, Miller NE, Novack TA, Cook EW 3rd, Fleming WC, Nepomuceno CS, Connell JS, Crago JE. Technique to improve chronic motor deficit after stroke. Arch Phys Med Rehabil. 1993;74(4):347-54. [PMID: 8466415]

58. Jørgensen L, Jacobsen BK. Changes in muscle mass, fat mass, and bone mineral content in the legs after stroke: A 1 year prospective study. Bone. 2001;28(6):655-59. [PMID: 11425655]

59. Ashe MC, Fehling P, Eng JJ, Khan KM, McKay HA. Bone geometric response to chronic disuse following stroke: A pQCT study. J Musculoskelet Neuronal Interact. 2006;6(3):226-33. [PMID: 17142942]

60. Pang MY, Ashe MC, Eng JJ. Muscle weakness, spasticity and disuse contribute to demineralization and geometric changes in the radius following chronic stroke. Osteoporos Int. 2007;18(9):1243-52. [PMID: 17401512]

61. Del Puente A, Pappone N, Mandes MG, Mantova D, Scarpa R, Oriente P. Determinants of bone mineral density in immobilization: A study on hemiplegic patients. Osteoporos Int. 1996;6(1):50-54. [PMID: 8845600]

62. Naftchi NE, Viau AT, Marshall CH, Davis WS, Lowman EW. Bone mineralization in the distal forearm of hemiplegic patients. Arch Phys Med Rehabil. 1975;56(11):487-92. [PMID: 1200819]

63. Sato Y, Oizumi K, Kuno H, Kaji M. Effect of immobilization upon renal synthesis of 1,25-dihydroxyvitamin $\mathrm{D}$ in disabled elderly stroke patients. Bone. 1999;24(3):271-75. [PMID: 10071922]

64. Iwamoto J, Takeda T, Ichimura S. Effect of exercise training and detraining on bone mineral density in postmenopausal women with osteoporosis. J Orthop Sci. 2001;6(2): 128-32. [PMID: 11484097]

65. Sato Y, Asoh T, Kaji M, Oizumi K. Beneficial effect of intermittent cyclical etidronate therapy in hemiplegic patients following an acute stroke. J Bone Miner Res. 2000;15(12):2487-94. [PMID: 11127214$]$

66. Sato Y, Fujimatsu Y, Kikuyama M, Kaji M, Oizumic K. Influence of immobilization on bone mass and bone metabolism in hemiplegic elderly patients with a longstanding stroke. J Neurol Sci. 1998;156(2):205-10. [PMID: 9588859]

67. Sato Y, Honda Y, Kuno H, Oizumi K. Menatetrenone ameliorates osteopenia in disuse-affected limbs of vitamin Dand K-deficient stroke patients. Bone. 1998;23(3):291-96. [PMID: 9737352]

68. Karlsson M. Does exercise reduce the burden of fractures? A review. Acta Orthop Scand. 2002;73(6):691-705. [PMID: 12553521]
69. Sato Y, Honda Y, Iwamoto J, Kanoko T, Satoh K. Effect of folate and mecobalamin on hip fractures in patients with stroke: A randomized controlled trial. JAMA. 2005; 293(9):1082-88. [PMID: 15741530$]$

70. Karlsson M. Has exercise an antifracture efficacy in women? Scand J Med Sci Sports. 2004;14(1):2-15. [PMID: 14723782]

71. Macko RF, Ivey FM, Forrester LW, Hanley D, Sorkin JD, Katzel LI, Silver KH, Goldberg AP. Treadmill exercise rehabilitation improves ambulatory function and cardiovascular fitness in patients with chronic stroke: A randomized, controlled trial. Stroke. 2005;36(10):2206-11. [PMID: 16151035]

72. Dean CM, Shepherd RB. Task-related training improves performance of seated reaching tasks after stroke. A randomized controlled trial. Stroke. 1997;28(4):722-28. [PMID: 9099186]

73. Duncan P, Richards L, Wallace D, Stoker-Yates J, Pohl P, Luchies C, Ogle A, Studenski S. A randomized, controlled pilot study of a home-based exercise program for individuals with mild and moderate stroke. Stroke. 1998; 29(10):2055-60. [PMID: 9756581$]$

74. Cheng PT, Wu SH, Liaw MY, Wong AM, Tang FT. Symmetrical body-weight distribution training in stroke patients and its effect on fall prevention. Arch Phys Med Rehabil. 2001;82(12):1650-54. [PMID: 11733877]

75. Kwakkel G, Van Peppen R, Wagenaar RC, Wood Dauphinee S, Richards C, Ashburn A, Miller K, Lincoln N, Partridge C, Wellwood I, Langhorne P. Effects of augmented exercise therapy time after stroke: A meta-analysis. Stroke. 2004;35(11):2529-39. [PMID: 15472114]

76. Marigold DS, Eng JJ, Dawson AS, Inglis JT, Harris JE, Gylfadóttir S. Exercise leads to faster postural reflexes, improved balance and mobility, and fewer falls in older persons with chronic stroke. J Am Geriatr Soc. 2005; 53(3):416-23. [PMID: 15743283]

77. Vearrier LA, Langan J, Shumway-Cook A, Woollacott M. An intensive massed practice approach to retraining balance post-stroke. Gait Posture. 2005;22(2):154-63. [PMID: 16139751]

78. Lachenbruch PA, Reinsch S, MacRae PG, Tobis JS. Adjusting for recall bias with the proportional hazards model. Methods Inf Med. 1991;30(2):108-10. [PMID: 1857244]

79. Wolf SL, Winstein CJ, Miller JP, Taub E, Uswatte G, Morris D, Giuliani C, Light KE, Nichols-Larsen D; EXCITE Investigators. Effect of constraint-induced movement therapy on upper extremity function 3 to 9 months after stroke: The EXCITE randomized clinical trial. JAMA. 2006; 296(17):2095-2104. [PMID: 17077374]

80. Green J, Forster A, Bogle S, Young J. Physiotherapy for patients with mobility problems more than 1 year after 
stroke: A randomised controlled trial. Lancet. 2002; 359(9302):199-203. [PMID: 11812553]

81. Taaffe DR, Duret C, Wheeler S, Marcus R. Once-weekly resistance exercise improves muscle strength and neuromuscular performance in older adults. J Am Geriatr Soc. 1999;47(10):1208-14. [PMID: 10522954]

82. Nguyen TV, Center JR, Eisman JA. Osteoporosis in elderly men and women: Effects of dietary calcium, physical activity, and body mass index. J Bone Miner Res. 2000; 15(2):322-31. [PMID: 10703935]

83. Uusi-Rasi K, Sievänen H, Pasanen M, Oja P, Vuori I. Maintenance of body weight, physical activity and calcium intake helps preserve bone mass in elderly women. Osteoporos Int. 2001;12(5):373-79. [PMID: 11444085]

84. Lau EM, Suriwongpaisal P, Lee JK, Das De S, Festin MR, Saw SM, Khir A, Torralba T, Sham A, Sambrook P. Risk factors for hip fracture in Asian men and women: The Asian osteoporosis study. J Bone Miner Res. 2001; 16(3):572-80. [PMID: 11277276]

85. Bennell K, Khan K, McKay H. The role of physiotherapy in the prevention and treatment of osteoporosis. Man Ther. 2000;5(4):198-213. [PMID: 11052899]

86. Kerr D, Ackland T, Maslen B, Morton A, Prince R. Resistance training over 2 years increases bone mass in calciumreplete postmenopausal women. J Bone Miner Res. 2001; 16(1):175-81. [PMID: 11149482]

87. Chien MY, Wu YT, Hsu AT, Yang RS, Lai JS. Efficacy of a 24-week aerobic exercise program for osteopenic postmenopausal women. Calcif Tissue Int. 2000;67(6):443-48. [PMID: 11289692]

88. Welsh L, Rutherford OM. Hip bone mineral density is improved by high-impact aerobic exercise in postmenopausal women and men over 50 years. Eur J Appl Physiol Occup Physiol. 1996;74(6):511-17. [PMID: 8971492]

89. Kemmler W, Engelke K, Lauber D, Weineck J, Hensen J, Kalender WA. Exercise effects on fitness and bone mineral density in early postmenopausal women: 1-year EFOPS results. Med Sci Sports Exerc. 2002;34(12):2115-23. [PMID: 12471325]

90. Rhodes EC, Martin AD, Taunton JE, Donnelly M, Warren J, Elliot J. Effects of one year of resistance training on the relation between muscular strength and bone density in elderly women. Br J Sports Med. 2000;34(1):18-22. [PMID: 10690445$]$

91. Ryan AS, Ivey FM, Hurlbut DE, Martel GF, Lemmer JT, Sorkin JD, Metter EJ, Fleg JL, Hurley BF. Regional bone mineral density after resistive training in young and older men and women. Scand J Med Sci Sports. 2004;14(1): 16-23. [PMID: 14723783]

92. Vincent KR, Braith RW. Resistance exercise and bone turnover in elderly men and women. Med Sci Sports Exerc. 2002;34(1):17-23. [PMID: 11782642]
93. Adami S, Gatti D, Braga V, Bianchini D, Rossini M. Sitespecific effects of strength training on bone structure and geometry of ultradistal radius in postmenopausal women. J Bone Miner Res. 1999;14(1):120-24. [PMID: 9893073]

94. Liu-Ambrose TY, Khan KM, Eng JJ, Heinonen A, McKay HA. Both resistance and agility training increase cortical bone density in 75- to 85-year-old women with low bone mass: A 6-month randomized controlled trial. J Clin Densitom. 2004;7(4):390-98. [PMID: 15618599]

95. Burr DB, Turner CH. Biomechanics of bone. In: Favus MJ, editor. Primer on the metabolic bone diseases and disorders of mineral metabolism. 5th ed. Washington (DC): American Society for Bone and Mineral Research; 2003. p. 58-64.

96. Pang MY, Ashe MC, Eng JJ, McKay HA, Dawson AS. A 19-week exercise program for people with chronic stroke enhances bone geometry at the tibia: A peripheral quantitative computed tomography study. Osteoporos Int. 2006; 17(11):1615-25. [PMID: 16896509]

97. Melton LJ 3rd, Atkinson EJ, O’Connor MK, O’Fallon WM, Riggs BL. Bone density and fracture risk in men. J Bone Miner Res. 1998;13(12):1915-23. [PMID: 9844110]

98. Sato Y, Maruoka H, Oizumi K. Amelioration of hemiplegiaassociated osteopenia more than 4 years after stroke by 1 alpha-hydroxyvitamin D3 and calcium supplementation. Stroke. 1997;28(4):736-39. [PMID: 9099188]

99. Sato Y, Kuno H, Kaji M, Saruwatari N, Oizumi K. Effect of ipriflavone on bone in elderly hemiplegic stroke patients with hypovitaminosis D. Am J Phys Med Rehabil. 1999;78(5):457-63. [PMID: 10493456]

100. Ryan AS, Dobrovolny CL, Smith GV, Silver KH, Macko RF. Hemiparetic muscle atrophy and increased intramuscular fat in stroke patients. Arch Phys Med Rehabil. 2002; 83(12):1703-7. [PMID: 12474173]

101. Hughes VA, Frontera WR, Dallal GE, Lutz KJ, Fisher EC, Evans WJ. Muscle strength and body composition: Associations with bone density in older subjects. Med Sci Sports Exerc. 1995;27(7):967-74. [PMID: 7564983]

102. Ozdurak RH, Düz S, Arsal G, Akinci Y, Kablan N, Iikli S, Korkusuz F. Quantitative forearm muscle strength influences radial bone mineral density in osteoporotic and healthy males. Technol Health Care. 2003;11(4):253-61. [PMID: 14600336]

103. Turner $\mathrm{CH}$, Robling AG. Designing exercise regimens to increase bone strength. Exerc Sport Sci Rev. 2003;31(1): 45-50. [PMID: 12562170]

104. Whitney C, Warburton DE, Frohlich J, Chan SY, McKay $\mathrm{H}$, Khan K. Are cardiovascular disease and osteoporosis directly linked? Sports Med. 2004;34(12):779-807. [PMID: 15462612] 
105. Magnus JH, Broussard DL. Relationship between bone mineral density and myocardial infarction in US adults. Osteoporos Int. 2005;16(12):2053-62. [PMID: 16249840]

106. Von der Recke P, Hansen MA, Hassager C. The association between low bone mass at the menopause and cardiovascular mortality. Am J Med. 1999;106(3):273-78.

[PMID: 10190374]

107. Rodriguez Garcia M, Naves Diaz M, Cannata Andia JB. Bone metabolism, vascular calcifications and mortality: Associations beyond mere coincidence. J Nephrol. 2005; 18(4):458-63. [PMID: 16245255]

108. Mundy G, Garrett R, Harris S, Chan J, Chen D, Rossini G, Boyce B, Zhao M, Gutierrez G. Stimulation of bone formation in vitro and in rodents by statins. Science. 1999; 286(5446):1946-49. [PMID: 10583956]

109. Maritz FJ, Conradie MM, Hulley PA, Gopal R, Hough S. Effect of statins on bone mineral density and bone histomorphometry in rodents. Arterioscler Thromb Vasc Biol. 2001;21(10):1636-41. [PMID: 11597938]

110. Maeda T, Matsunuma A, Kawane T, Horiuchi N. Simvastatin promotes osteoblast differentiation and mineralization in MC3T3-E1 cells. Biochem Biophys Res Commun. 2001;280(3):874-77. [PMID: 11162604]

111. Bjarnason NH, Riis BJ, Christiansen C. The effect of fluvastatin on parameters of bone remodeling. Osteoporos Int. 2001;12(5):380-84. [PMID: 11444086]

112. Watanabe S, Fukumoto S, Takeuchi Y, Fujita H, Nakano T, Fujita T. Effects of 1-year treatment with fluvastatin or pravastatin on bone. Am J Med. 2001;110(7):584-87. [PMID: 11343673]

113. Hinkleman LL, Nieman DC. The effects of a walking program on body composition and serum lipids and lipoproteins in overweight women. J Sports Med Phys Fitness. 1993;33(1):49-58. [PMID: 8350608$]$

114. Lokey EA, Tran ZV. Effects of exercise training on serum lipid and lipoprotein concentrations in women: A metaanalysis. Int J Sports Med. 1989;10(6):424-29.

[PMID: 2628361]

115. Nieman DC, Warren BJ, O’Donnell KA, Dotson RG, Butterworth DE, Henson DA. Physical activity and serum lipids and lipoproteins in elderly women. J Am Geriatr Soc. 1993;41(12):1339-44. [PMID: 8227917]

116. Hambrecht R, Fiehn E, Weigl C, Gielen S, Hamann C, Kaiser R, Yu J, Adams V, Niebauer J, Schuler G. Regular physical exercise corrects endothelial dysfunction and improves exercise capacity in patients with chronic heart failure. Circulation. 1998;98(24):2709-15.

[PMID: 9851957]

117. Hambrecht R, Wolf A, Gielen S, Linke A, Hofer J, Erbs S, Schoene N, Schuler G. Effect of exercise on coronary endothelial function in patients with coronary artery dis- ease. N Engl J Med. 2000;342(7):454-60.

[PMID: 10675425$]$

118. Maiorana A, O’Driscoll G, Dembo L, Cheetham C, Goodman C, Taylor R, Green D. Effect of aerobic and resistance exercise training on vascular function in heart failure. Am J Physiol Heart Circ Physiol. 2000;279(4): H1999-2005. [PMID: 11009490]

119. Roth EJ. Heart disease in patients with stroke: Incidence, impact, and implications for rehabilitation. Part 1: Classification and prevalence. Arch Phys Med Rehabil. 1993; 74(7):752-60. [PMID: 8328899]

120. Hsieh YF, Turner CH. Effects of loading frequency on mechanically induced bone formation. J Bone Miner Res. 2001;16(5):918-24. [PMID: 11341337]

121. Rubin CT, Lanyon LE. Regulation of bone formation by applied dynamic loads. J Bone Joint Surg Am. 1984; 66(3):397-402. [PMID: 6699056]

122. Burr DB, Robling AG, Turner CH. Effects of biomechanical stress on bones in animals. Bone. 2002;30(5):781-86. [PMID: 11996920]

123. Umemura Y, Ishiko T, Yamauchi T, Kurono M, Mashiko S. Five jumps per day increase bone mass and breaking force in rats. J Bone Miner Res. 1997;12(9):1480-85. [PMID: 9286765]

124. Srinivasan S, Weimer DA, Agans SC, Bain SD, Gross TS. Low-magnitude mechanical loading becomes osteogenic when rest is inserted between each load cycle. J Bone Miner Res. 2002;17(9):1613-20. [PMID: 12211431]

125. Taaffe DR, Robinson TL, Snow CM, Marcus R. Highimpact exercise promotes bone gain in well-trained female athletes. J Bone Miner Res. 1997;12(2):255-60. [PMID: 9041058]

126. Söderman K, Bergström E, Lorentzon R, Alfredson H. Bone mass and muscle strength in young female soccer players. Calcif Tissue Int. 2000;67(4):297-303. [PMID: 11000343]

127. Pettersson U, Nordström P, Alfredson H, HenrikssonLarsén K, Lorentzon R. Effect of high impact activity on bone mass and size in adolescent females: A comparative study between two different types of sports. Calcif Tissue Int. 2000;67(3):207-14. [PMID: 10954774]

128. Heinonen A, Sievänen H, Kannus P, Oja P, Vuori I. Sitespecific skeletal response to long-term weight training seems to be attributable to principal loading modality: A pQCT study of female weightlifters. Calcif Tissue Int. 2002;70(6):469-74. [PMID: 12016461$]$

129. Alfredson H, Nordström P, Lorentzon R. Bone mass in female volleyball players: A comparison of total and regional bone mass in female volleyball players and nonactive females. Calcif Tissue Int. 1997;60(4):338-42. [PMID: 9075629] 
130. Alfredson H, Nordström P, Pietilä T, Lorentzon R. Longterm loading and regional bone mass of the arm in female volleyball players. Calcif Tissue Int. 1998;62(4):303-8. [PMID: 9504954$]$

131. Bennell KL, Malcolm SA, Khan KM, Thomas SA, Reid SJ, Brukner PD, Ebeling PR, Wark JD. Bone mass and bone turnover in power athletes, endurance athletes, and controls: A 12-month longitudinal study. Bone. 1997; 20(5):477-84. [PMID: 9145246]

132. Wittich A, Mautalen CA, Oliveri MB, Bagur A, Somoza F, Rotemberg E. Professional football (soccer) players have a markedly greater skeletal mineral content, density and size than age- and BMI-matched controls. Calcif Tissue Int. 1998;63(2):112-17. [PMID: 9685514]

133. Orwoll ES, Ferar J, Oviatt SK, McClung MR, Huntington K. The relationship of swimming exercise to bone mass in men and women. Arch Intern Med. 1989;149(10):2197-2200. [PMID: 2802886]

134. Rico H, Revilla M, Hernández ER, Gómez-Castresana F, Villa LF. Bone mineral content and body composition in postpubertal cyclist boys. Bone. 1993;14(2):93-95. [PMID: 8334038]

135. Taaffe DR, Snow-Harter C, Connolly DA, Robinson TL, Brown MD, Marcus R. Differential effects of swimming versus weight-bearing activity on bone mineral status of eumenorrheic athletes. J Bone Miner Res. 1995;10(4): 586-93. [PMID: 7610929]

136. Kerr D, Morton A, Dick I, Prince R. Exercise effects on bone mass in postmenopausal women are site-specific and load-dependent. J Bone Miner Res. 1996;11(2):218-25. [PMID: 8822346]

137. Jensen J, Lundin-Olsson L, Nyberg L, Gustafson Y. Fall and injury prevention in older people living in residential care facilities. A cluster randomized trial. Ann Intern Med. 2002;136(10):733-41. [PMID: 12020141]

138. Kannus P, Parkkari J, Niemi S, Pasanen M, Palvanen M, Järvinen M, Vuori I. Prevention of hip fracture in elderly people with use of a hip protector. N Engl J Med. 2000; 343(21):1506-13. [PMID: 11087879]

139. Willig R, Luukinen H, Jalovaara P. Factors related to occurrence of hip fracture during a fall on the hip. Public Health. 2003;117(1):25-30. [PMID: 12802901]

140. Campbell AJ. Purity, pragmatism and hip protector pads. Age Ageing. 2001;30(6):431-32. [PMID: 11742764$]$

141. Liu-Ambrose T, Khan KM, Eng JJ, Janssen PA, Lord SR, McKay HA. Resistance and agility training reduce fall risk in women aged 75 to 85 with low bone mass: A 6month randomized, controlled trial. J Am Geriatr Soc. 2004;52(5):657-65. [PMID: 15086643]

142. Cranney A, Guyatt G, Krolicki N, Welch V, Griffith L, Adachi JD, Shea B, Tugwell P, Wells G; Osteoporosis Research Advisory Group (ORAG). A meta-analysis of etidronate for the treatment of postmenopausal osteoporosis. Osteoporos Int. 2001;12(2):140-51. [PMID: 11303715]

143. Sato Y, Iwamoto J, Kanoko T, Satoh K. Risedronate sodium therapy for prevention of hip fracture in men 65 years or older after stroke. Arch Intern Med. 2005;165(15):1743-48. [PMID: 16087822]

144. Uusi-Rasi K, Kannus P, Cheng S, Sievänen H, Pasanen M, Heinonen A, Nenonen A, Halleen J, Fuerst T, Genant $\mathrm{H}$, Vuori I. Effect of alendronate and exercise on bone and physical performance of postmenopausal women: A randomized controlled trial. Bone. 2003;33(1):132-43. [PMID: 12919708]

145. Sato Y, Iwamoto J, Kanoko T, Satoh K. Low-dose vitamin D prevents muscular atrophy and reduces falls and hip fractures in women after stroke: A randomized controlled trial. Cerebrovasc Dis. 2005;20(3):187-92. [PMID: 16088114$]$

146. Ramnemark A, Nilsson M, Borssén B, Gustafson Y. Stroke, a major and increasing risk factor for femoral neck fracture. Stroke. 2000;31(7):1572-77. [PMID: 10884456]

Submitted for publication January 26, 2007. Accepted in revised form July 30, 2007. 